\title{
Sulphydryl Requirement for Insulin Release from the Perfused Pancreas
}

\author{
Studies with Ethacrynic Acid and Dithiothreitol \\ M. M. C. Landgraf-Leurs, L. Mayer, and R. Landgraf \\ Medizinische Klinik Innenstadt, University of Munich, Munich, FRG
}

Summary. Using the isolated, perfused rat pancreas the importance of sulphydryl groups for the secretory process of insulin was investigated. It was found that ethacrynic acid (EA, $0.075-0.6 \mathrm{mmol} / \mathrm{l}$ ) caused a dose-dependent, monophasic insulin release. Addition of EA to a glucose-stimulated ( $20 \mathrm{mmol} / \mathrm{l})$ pancreas led to a sudden increase in hormone release, followed by a dose-dependent inhibition of release, which was not reversible after removal of EA. The same phenomenon was seen in the presence of $20 \mathrm{mmol} / 1$ leucine. Dithiothreitol (DTT, 0.1 and $1 \mathrm{mmol} / \mathrm{l}$ ) had no effect on basal insulin secretion. Added to a glucose-stimulated pancreas DTT $(1 \mathrm{mmol} / \mathrm{l})$ caused a reversible inhibition of insulin release. The persistent inhibitory action of EA on glucose-induced insulin release could be reversed by simultaneous perfusion of EA and DTT. Sequential exposure of a glucose-stimulated pancreas to EA and DTT led to a rapid release of insulin, due to DTT; however, the EA-induced inhibition of insulin secretion could not be prevented. Two kinds of thiol groups in the plasma membrane and in the beta cell might be responsible for the various kinetics of insulin release induced by EA and DTT.

Key words: Perfused pancreas, insulin, sulphydryl groups, ethacrynic acid, dithiothreitol, glucose, leucine.

Exposure of isolated islets to glycosidases [1] or pronase [2] changed considerably glucose-induced insulin secretion. These experimental data support the concept that membrane-receptor-sites are involved in the sequence of events leading to insulin release.
A variety of thiol-blocking agents (iodoacetate and iodoacetamide [3], organic mercurials [4] and electronegative disulphides [5]) can stimulate insulin release. These findings, together with the fact that thiol compounds like glutathione were able to modulate the secretory response to glucose [6], point to the role of thiol groups in the beta-cell membrane in the process of insulin release.

Ethacrynic acid (EA), another potent sulphydrylgroup blocking reagent, has been shown to prevent glyceryl-trinitrate-induced relaxation of smooth muscle, while dithiothreitol (DTT) has the opposite effect [7]. Since EA might also influence glucose tolerance, it is an interesting substance for further study of the role of SH-groups in the process of insulin secretion. Therefore, perfusions of isolated rat pancreas with each drug alone, with both drugs together and with the drugs in combination with glucose or leucine were performed.

\section{Materials and Methods}

\section{Materials}

D-glucose and L-leucine were obtained from Merck AG, Darmstadt. Ethacrynic acid (sodium salt) was from Merck, Sharp and Dohme, Munich, and dithiothreitol (Cleland reagent) from Serva, Heidelberg. Bovine serum albumin (electrophoretic purity 100\%) was purchased from Behringwerke, Marburg. Dextran (MW 60,000-80,000) from Knoll AG, Ludwigshafen, was dialyzed against twice distilled water to remove traces of contaminating glucose. The other reagents used were of analytical grade form Merck, Darmstadt.

\section{Animals and Perfusion Procedure}

Male Sprague-Dawley rats, weighing between $160-350 \mathrm{~g}$, fed ad libitum with Altromin ${ }^{\circledR}$, were used as pancreas donors. Details of the isolation and perfusion procedure are described elsewhere [8, 9]. 


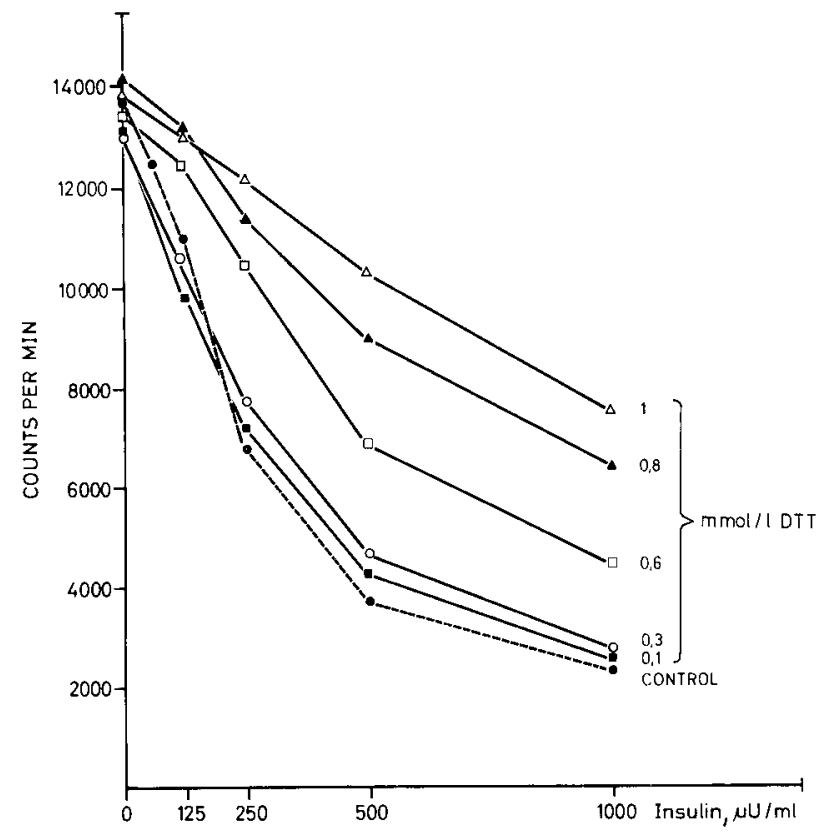

Fig. 1. Influence of dithiothreitol on the immunoreactivity of insulin. DTT at the various concentration was added to standard insulin samples, which were stored for about 48 hours at $-20^{\circ} \mathrm{C}$ Afterward radioimmunoassays were performed. As shown in the figure binding of the iodinated tracer to the insulin antibody was not significantly altered by DTT. One of three identical experiments with effectively the same results is shown

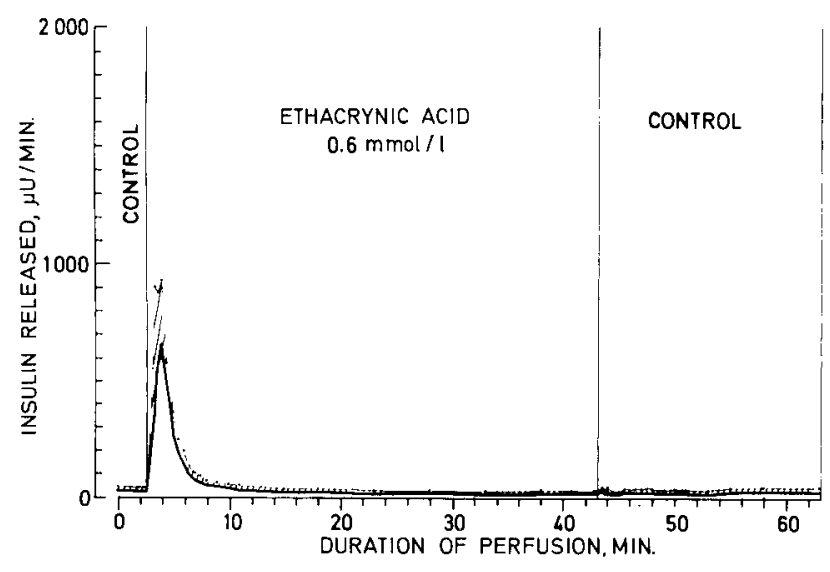

Fig. 2. Kinetics of insulin release induced by ethacrynic acid $(0.6 \mathrm{mmol} / \mathrm{l})$. Mean values \pm SEM (shaded area) for 4 animals. No glucose was present

The collecting tubes contained a small volume of pure bovine serum albumin (final concentration $0.65 \mathrm{~g} / 100 \mathrm{ml}$ ) to prevent insulin adsorption. The samples were stored at $-20^{\circ} \mathrm{C}$.

Insulin in the perfusate was determined by radioimmunoassay [10], with minor modifications for semiautomatic analysis [11]. Human insulin was used as the standard, since human and rat insulin gave identical standard curves with the antibody used, provided that bovine serum albumin at the above concentration was added to the rat insulin standard samples. Glucose, leucine and EA did not affect the radioimmunoassay. However, as shown in Figure 1, the immunoreactivity of insulin, stored at $-20^{\circ} \mathrm{C}$ in a
Table 1. Effect of ethacrynic acid (EA) concentration on insulin response during the first five minutes of perfusion with $\mathrm{EA}$. No glucose was present. Results are mean values \pm SEM. The Student t-test was applied for statistical analysis

\begin{tabular}{|c|c|c|c|}
\hline $\begin{array}{l}\mathrm{EA} \\
\mathrm{mmol} / 1\end{array}$ & $\mathrm{n}$ & $\begin{array}{l}\text { Integrated insulin } \\
\text { release } \\
\mu U / \text { min }\end{array}$ & p-values \\
\hline 0 & 11 & $31 \pm 8$ & \\
\hline 0.015 & 1 & 31 & NS \\
\hline 0.075 & 3 & $83 \pm 18$ & $<0.01$ \\
\hline 0.12 & 3 & $90 \pm 15$ & $<0.005$ \\
\hline 0.60 & 4 & $257 \pm 93$ & $<0.001$ \\
\hline
\end{tabular}

solution containing DTT, decreased, depending on the DTT concentration. Samples, obtained in experiments in which DTT was perfused, were therefore compared with standard samples, preincubated for the same time with corresponding DTT concentrations.

\section{Results}

\section{Effect of EA on Insulin Release}

In the absence of glucose, EA induced a monophasic insulin release, which was most pronounced at the highest dose tested (Fig. 2). Table 1 shows the dosedependency of the integrated insulin response during the first five minutes of exposure to EA.

When EA was added during the second phase of glucose $(20 \mathrm{mmol} / \mathrm{l})$ - induced insulin release, an immediate dose-dependent burst of insulin secretion was followed by a dose-dependent inhibition of the glucose-stimulated insulin release (Fig. 3). Very low concentration of EA $(0.075 \mathrm{mmol} / \mathrm{l})$ only caused a slow inhibition of glucose-provoked insulin release. The inhibition of insulin release was not reversible upon removal of EA, although the glucose perfusion was continued.

The same stimulatory and inhibitory phenomena were seen when leucine $(20 \mathrm{mmol} / \mathrm{l})$ was present instead of glucose before, during and after exposure of the pancreas to $0.6 \mathrm{mmol} / \mathrm{l} \mathrm{EA}$ (Fig. 4).

\section{Effect of DTT on Insulin Release}

DTT $(1 \mathrm{mmol} / \mathrm{l})$ with or without substimulatory levels of glucose $(3 \mathrm{mmol} / \mathrm{l})$ did not cause any insulin release. After a preperfusion with $20 \mathrm{mmol} / 1$ glucose the addition of a low concentration of DTT $(0.1 \mathrm{mmol} / \mathrm{l})$ did not change the glucose-induced insulin release. In contrast $1 \mathrm{mmol} / 1 \mathrm{DTT}$ led to a strong, but reversible, inhibition of the glucoseinduced insulin release (Fig. 5). No further deinhibition was noted upon removal of DTT. 


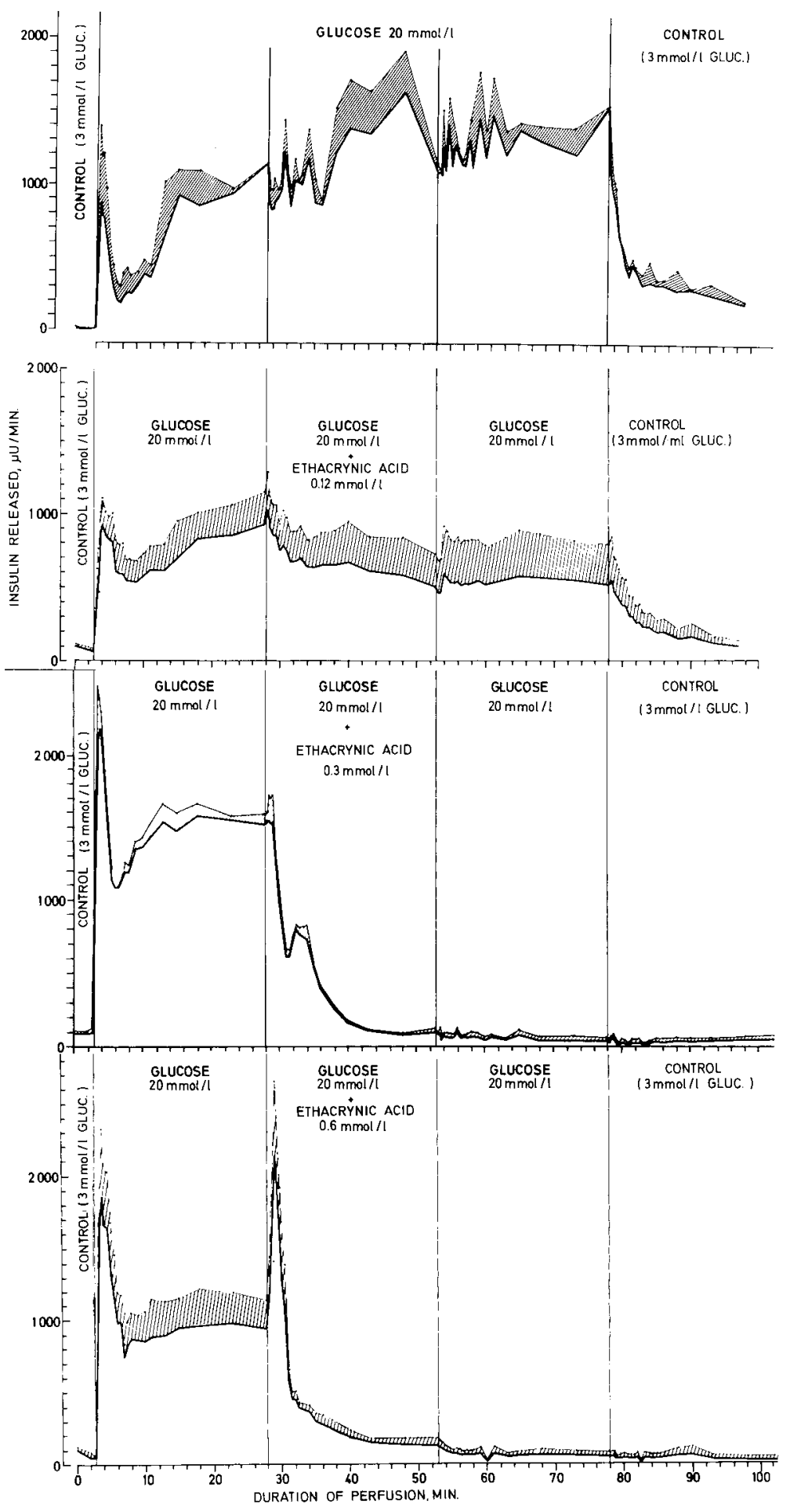

Fig. 3. Influence of various concentrations of ethacrynic acid on glucose-induced insulin release. Mean values \pm SEM (shaded area) for 4 $(0.12 \mathrm{mmol} / \mathrm{l}), 3(0.3 \mathrm{mmol} / 1)$ and $3(0.6 \mathrm{mmol} / \mathrm{l})$ animals. The top panel depicts the control experiments $(n=3)$ in which during the whole time 20 $\mathrm{mmol} / \mathrm{l}$ glucose was present. Switches to completely identical perfusion media were made at the same time intervals in order to have the same experimental conditions in all perfusions

Interaction of EA and DTT during Glucose-Induced Insulin Release

When EA $(0.12 \mathrm{mmol} / \mathrm{l})$ was added to a glucosestimulated pancreas a slow inhibition of insulin secretion occurred as described above (Fig. 3 and Fig. 6). Exchange of EA by $1 \mathrm{mmol} / 1$ DTT caused a sudden burst of insulin release, followed by a complete, irreversible inhibition of glucose-induced insulin secretion.

Simultaneous addition of DTT and EA to a glucose-stimulated pancreas led to an immediate insulin release, which was followed by a transitory inhibition and a steady increase of insulin secretion, although EA plus DTT were still present in the perfusate (Fig. 7). Upon removal of EA plus DTT, with con- 

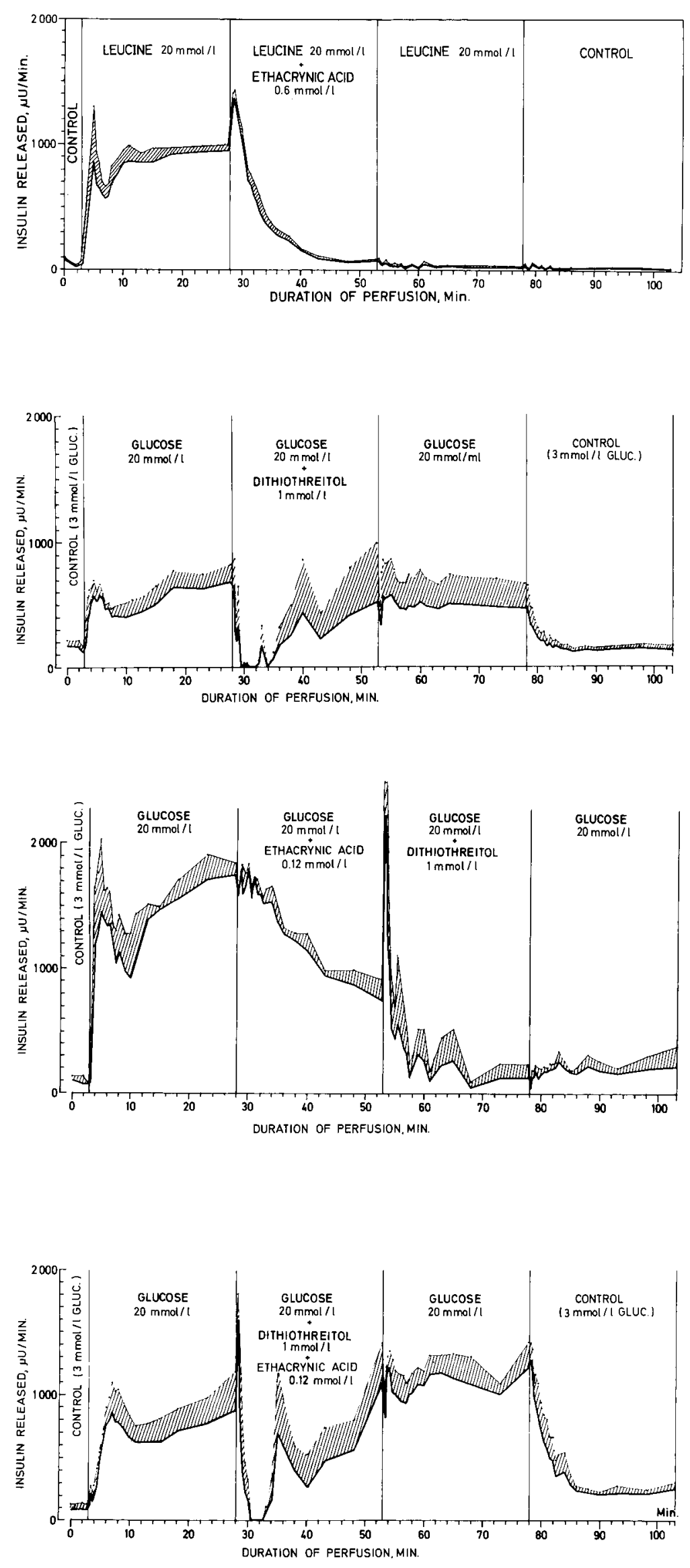

Fig. 4. Influence of ethacrynic acid $(0.6 \mathrm{mmol} / \mathrm{i})$ on leucine-induced insulin release. Mean values \pm SEM (shaded area) for 3 animals. During the whole experiments no glucose was present

Fig. 5. Influence of dithiothreitol $(1 \mathrm{mmol} / \mathrm{l})$ on glucose-induced insulin release. Mean values \pm SEM (shaded area) for 3 animals

Fig. 6. Effect of dithiothreitol on ethacrynic acidinduced inhibition of glucose-stimulated insulin release. Mean values \pm SEM (shaded area) for 3 animals

Fig. 7. Influence of ethacrynic acid plus dithiothreitol on glucose-induced insulin release. Mean values \pm SEM (shaded area) for 3 animals 
tinuation of the glucose perfusion, the insulin secretion remained at a level expected with $20 \mathrm{mmol} / \mathrm{lglu}-$ cose alone.

\section{Discussion}

The importance of sulphydryl groups in secretory processes was first stressed by Douglas et al. [12] for vasopressin and by Schofield [13] for growth hormone. Our data indicate that binding of EA to sulphydryl groups at the cell membrane or inside the beta cell causes insulin release without the requirement of any substrate. Since the amount of insulin released is clearly dependent on the concentration of EA, it is possible that the number of sulphydryl groups blocked by alkylation is related to the amount of insulin released. The secretory mechanism induced by EA seems to be different from that provoked by glucose or leucine, since the secretion kinetics of these substances are quite different. EA, furthermore, induces an initial additive insulin release when perfused together with glucose or leucine.

The enhancement of insulin release upon addition of EA with or without glucose or leucine might be due to conformational changes of the beta-cell membrane caused by the binding of EA to SHgroups in the plasma membrane. This might induce sudden changes in ionic fluxes across the membrane resulting in depolarization of the beta-cell and insulin release. An increase in the permeability of the betacell membrane for monovalent cations after binding of organic mercurials inducing similar insulin secretory profiles has been found by Sehlin and Täljedal [14]. This change in transmembrane ionic fluxes might influence the activity of a NaK-ATPase demonstrated in islets $[15,16]$. SH-group blocking agents like $\mathrm{p}$-(chloromercuri)benzenesulphonic acid (p-CMBS) also directly influence ATPase activity [15]. It is therefore conceivable that EA may increase the insulin secretory capacity in a way similar to that of ouabain.

The slow inhibitory action of EA on insulin secretion may be due to a slow penetration of this drug into the beta cell, where it probably binds to $\mathrm{SH}$ groups of enzymes of glycolysis and oxidative phosphorylation, as demonstrated in cell free preparations [17, 18] and in intact cells [19-21]. Slow penetration into the beta-cell could be measured for other SH-groups blocking agents [5, 22-24]. The persistence of inhibition after removal of EA might be due to a long-lasting inhibition of the energy metabolism in the islets due to covalently bound $\mathrm{EA}$ to $\mathrm{SH}$ groups of key enzymes in intermediary metabolism. The same kind of double action discussed for EA has been found by Hellman et al. for iodoacetamide [3].
Stabilization of SH-groups or reduction of disulphide bridges at the beta-cell membrane by dithiothreitol did not cause insulin release by itself. This is in agreement with a study conducted with other thiols [6]. Addition of DTT to a glucose-stimulated pancreas led to an abrupt but reversible inhibition of insulin secretion. That this inhibition is reversible, although DTT is still present, might indicate that a new equilibrium between sulphydryl groups and disulphides is reached which seems necessary for insulin release [23]. Hellman et al. reported that thiols, like reduced glutathione or 1-thio-D-glucose, potentiated glucose-provoked insulin secretion, while another thiol reagent was inert [6]. The potentiating effect was, however, only seen at a concentration of $0.1 \mathrm{mmol} / 1$ and not at $0.5 \mathrm{mmol} / 1$. Since we could not demonstrate any effect of DTT at low concentration $(0.1 \mathrm{mmol} / \mathrm{l})$ and a marked inhibitory action at $1 \mathrm{mmol} / \mathrm{l}$ our results do not confirm those of Hellman et al. [6]. This disagreement is, besides the completely different experimental conditions and the different reducing capacity of the thiols used in both studies, not readily explained.

That more than simple oxidation and reduction of $\mathrm{SH}$-groups is involved in the actions of EA and DTT is shown in the experiments in which EA and DTT are perfused in sequence or in combination. DTT, when added together with EA, provoked a sudden burst of insulin release, which was followed first by an inhibition and later by a deinhibition of insulin release. Comparable interaction of DTT and EA was found by Ferrendelli et al. [25] who reported that the suppression of the adenylate cyclase activity in brain homogenates by EA could be fully restored by DTT, but only when added before or simultaneously with EA.

In the experiments in which glucose plus EA was followed by glucose plus DTT a rapid release phase again occurred, but now DTT was unable to prevent the EA-induced inhibition of stimulated insulin release. The sudden insulin release in both sets of experiments is probably due to rapid changes in the redox state of SH-groups in the plasma membrane.

The succeeding inhibition and deinhibition phenomena might reflect transport and intracellular binding of EA and DTT. DTT when added together with EA might prevent EA entry into the cell and thereby block the inhibitory action of EA on intermediary metabolism or it might prevent alkylation of free $\mathrm{SH}$-groups in the membrane or the cytosol. As soon as SH-groups are alkylated by EA, DTT, added afterwards, is unable to reverse this binding.

Acknowledgements. We are grateful to Merck, Sharp and Dohme for the generous supply of ethacrynic acid. This study was supported by Deutsche Forschungsgemeinschaft SFB 51/C-12. 


\section{References}

1. Maier, V., Schatz, H., Hinz, M., Pfeiffer, E. F., Blessing, J.: Biosynthesis and secretion of insulin after treatment of pancreatic islets of mice with several glycosidases. Endokrinologie 62, 269-278 (1973)

2. Lambert, A. E., Henquin, J.C., Orci, L., Renold, A. E.: Enzyme-induced modifications of beta-cell function. I. Effect of pronase on insulin secretion. Eur. J. Clin. Invest. 4, 459-468 (1974)

3. Hellman, B., Idahl, L. A., Lernmark, A., Sehlin, J. Täljedal, J.-B.: Iodoacetamide-induced sensitization of the pancreatic beta-cells to glucose stimulation. Biochem. J. 132, 775-789 (1973)

4. Bloom, G. D., Hellman, B., Idahl, L. A., Lernmark, A., Sehlin, J., Täljedal, J.-B.: Effects of organic mercurials on mammalian pancreatic $\beta$-cells. Biochem. J. 129, 241-254 (1972)

5. Hellman, B., Idahl, L. A., Lernmark, A., Sehlin, J., Täljedal, J.-B.: Role of thiol groups in insulin release: Studies with poorly permeating disulphides. Mol. Pharmacol. 9, 792-801 (1973)

6. Hellman, B., Idahl, L. A., Lernmark, A., Sehlin, J., Täljedal, J.-B.: Stimulation of insulin release by thiols. Biochim. Biophys. Acta 392, 101-109 (1975)

7. Needleman, Ph., Jakschik, B., and Johnson jr., E. M.: Sulfhydryl requirement for relaxation of vascular smooth muscle. J. Pharmacol. Exp. Ther. 187, 324-331 (1973)

8. Landgraf, R., Kotler-Brajtburg, J., Matschinsky, F. M.: Kinetics of insulin release from the perfused rat pancreas caused by glucose, glucosamine, and galactose. Proc. Natl. Acad. Sci. U.S.A. 68, 536-540 (1971)

9. Landgraf, R., Landgraf-Leurs, M. M. C., Hörl, R.: L-leucine and L-phenylalanine induced insulin release and the influence of D-glucose. Kinetic studies with the perfused rat pancreas. Diabetologia 10, 415-420 (1974)

10. Hales, C. N., Randle, P. J.: Immunoassay of insulin with insulin-antibody precipitate. Biochem. J. 88, 137-146 (1963)

11. Bottermann, P., Ermler, R., Henner, J.: A semiautomatic method for immunoassay for insulin and hGH. Horm. Metab. Res. 3, 55-59 (1971)

12. Douglas, W.W., Ishida, A., Poisner, A.M.: The effect of metabolic inhibitors on the release of vasopressin from the isolated neurohypophysis. J. Physiol. (Lond.) 181, 753-759 (1965)

13. Schofield, J. G.: Effect of sulphydryl reagents on the release of ox growth hormone in vitro. Biochim. Biophys. Acta 252, 516-525 (1971)

14. Sehlin, J., Täljedal, J.-B.: Sodium uptake by microdissected pancreatic islets: Effect of ouabain and chloromercuribenzene-p-sulphonic acid. FEBS Lett. 39, 209-213 (1974)

15. Kemmler, W., Löffler, G.: NaK-ATPase in rat pancreatic islets. Diabetologia 13, 235-238 (1977)

16. Formby, B., Capito, K., Hedeskov, C. J.: $\left(\mathrm{Na}^{+}, \mathrm{K}^{+}\right)$-activated ATPase in microsomes from mouse pancreatic islets. Acta Physiol. Scand. 96, 143-144 (1976)

17. Klahr, S., Yates, J., Bourgoignie, J.: Inhibition of glycolysis by ethacrynic acid and furosemide. Am. J. Physiol. 221, 1038-1043 (1971)

18. Kramar, R., Kaiser, E.: Hemmung von SH-Enzymen durch EA. Experientia 26, 485-486 (1970)

19. Jones, V. D., Landon, E. J.: The effect of ouabain, meralloride and ethacrynic acid on respiration and glycolysis in kidney slices. Biochem. Pharmacol. 16, 2163-2169 (1967)

20. Gordon, E. E.: Site of ethacrynic acid-action on Ehrlich ascites tumor cells. Biochem. Pharmacol. 17, 1237-1246 (1968)

21. Gordon, E. E., Hartog, M. de: The relationship between cell membrane potassium ion transport and glycolysis. The effect of ethacrynic acid. J. Gen. Physiol. 54, 650-663 (1969)

22. Hellman, B., Lernmark, A., Sehlin, J., Söderberg, M., Täljedal, J.-B.: The pancreatic beta-cell recognition of insulin secretagogues. VII. Binding and permeation of chloromercuribenzene-p-sulphonic acid in the plasma membrane of pancreatic beta-cells. Arch. Biochem. Biophys. 158, 435-441 (1973)

23. Hellman, B., Idahl, L., Lernmark, A., Sehlin, J., Täljedahl, J.B.: Membrane sulphydryl groups and the pancreatic beta cell recognition of insulin secretagogues. In: W. J. Malaisse, J. Pirart (eds.): Diabetes, pp. 65-78. Amsterdam: Excerpta Medica Int. Congr. Series No. 3121974

24. Söderberg, M.: Glucose inhibition of the permeation of chloromercuribenzene-p-sulphonic acid in the plasma membrane of pancreatic islets. Acta Endocrinol. (Kbh.) 79, 86-94 (1975)

25. Ferrendelli, J. A., Johnson, E. M., Chong, M. M., Needleman, P.: Inhibition of brain adenylcyclase by ethacrynic acid and dithiobisnitrobenzoic acid. Biochem. Pharmacol. 22, 3133-3136 (1973)

Received: February 2, 1978,

and in revised form: May 25, 1978

Dr. M. M. C. Landgraf-Leurs

Medizinische Klinik Innenstadt

der Universität

Ziemssenstraße 1

D-8000 München 2

Federal Republic of Germany 